\title{
Apolipoprotein E Genotype and Cardiovascular Diseases in the Elderly
}

\author{
Mary N. Haan • Elizabeth R. Mayeda
}

Published online: 16 July 2010

(C) The Author(s) 2010. This article is published with open access at Springerlink.com

\begin{abstract}
The apolipoprotein E (APOE) genotype is a genetic risk factor for dementia, Alzheimer's disease, and cardiovascular disease (CVD). It includes three alleles (e2, e3, e4) that are located on chromosome $19 \mathrm{q} 3.2$. The e 3 allele is the most common and is more common in people of Northern European ancestry and less common in those of Asian ancestry. Those with at least one e4 allele are at increased risk for CVD outcomes. It is well established that the presence of an e4 allele is linked to higher low-density lipoprotein cholesterol levels, even at young ages. Even though most CVD occurs in older people, there are few studies of the effects of APOE on CVD in older people. This review addresses recent research on the links between APOE, CVD, and vascular mechanisms by which APOE may affect CVD in the elderly.
\end{abstract}

Keywords Apolipoprotein E.Cardiovascular disease · Elderly

\section{Introduction}

In 2006, cardiovascular diseases (CVD) accounted for $34.3 \%$ of all deaths in the United States [1] (approximately

M. N. Haan $(\bowtie) \cdot$ E. R. Mayeda

School of Medicine,

Department of Epidemiology and Biostatistics,

University of California,

3333 California Street, Room 280,

San Francisco, CA 94118, USA

e-mail: Mary.Haan@ucsf.edu the deaths of 831,000 people). In that year, there were an estimated 74 million people with high blood pressure, nearly 18 million with coronary heart disease (CHD), and 6.4 million with strokes. The vast majority of these events and diagnoses occur among people aged $\geq 65$ years, such that the prevalence of heart disease and stroke in people over 65 years of age is nearly four times higher compared with people aged 18 to 64 years [2]. Personal health care expenditures in 2005 for Medicare recipients for heart disease, stroke, and hypertension totaled nearly $\$ 50,000$ per person [3]. According to statistics published by the National Center for Health Statistics, the prevalence of these conditions in the United States in people aged $\geq 65$ years declined by about $20 \%$ between 1999 and 2006 . However, it is likely that death from CVD in people with these conditions is simply being postponed, and that the decline in the death rates will lead to a potential future increase in CVD morbidity in people over the age of 80 years [1] because those who would have died instead survive with their condition and contribute to the overall population burden of CVD-related chronic conditions [1]. Treatments for CVD and prevention of risk factors for CVD have become more effective and more widely used. Statin drugs were used by 24 million Americans in 2003 and 2004 and their use is higher among people with higher levels of low-density lipoprotein cholesterol (LDL-C) who are aged $\geq 75$ years than among those aged 20 to 39 years [4]. Cigarette smoking is a prime example of this kind of change, as prevalence of smoking has declined and in 2006 to $2008,23 \%$ of those over age 18 years were current smokers compared with nearly $40 \%$ of those over 65 years of age. 
Studies of coronary heart disease, lipids, and coronary atherosclerosis from 2000 to 2010

\begin{tabular}{|c|c|c|c|c|c|c|c|c|}
\hline Study & Year & $\begin{array}{l}\text { Cases/sample } \\
\text { or controls }\end{array}$ & $\begin{array}{l}\text { Age } \\
\text { range, } y\end{array}$ & Ethnic group & Design & APOE allele & Outcome & $\begin{array}{l}\text { Risk estimate } \\
(95 \% \mathrm{CI})\end{array}$ \\
\hline $\begin{array}{l}\text { Slooter } \\
\text { et al. [20] }\end{array}$ & 2004 & $185 / 6852$ & $55+$ & Europeans & Cohort & $\mathrm{e} 3 / \mathrm{e} 4$ or e $4 / \mathrm{e} 4$ & MI & $\begin{array}{l}1.0(0.7-1.4) \\
1.7(0.8-3.6)\end{array}$ \\
\hline $\begin{array}{l}\text { Ward } \\
\text { et al. }[21 \cdot]\end{array}$ & 2009 & $2712 / 22,169$ & $40-79$ & Europeans & Cohort & Any $\mathrm{e}^{\mathrm{a}}$ & CHD & $1.09(1.0-1.19)$ \\
\hline $\begin{array}{l}\text { Scuteri } \\
{[11]}\end{array}$ & 2001 & $104 / 730$ & $21-96$ & US white men & Cohort & Any $\mathrm{e}^{\mathrm{a}}$ & Coronary events & $2.01(1.4-3.1)$ \\
\hline $\begin{array}{l}\text { Volcik } \\
\text { et al. [19] }\end{array}$ & 2006 & $447 / 12,491$ & $45-64$ & US whites and blacks & Cohort & Any e $4^{\mathrm{a}}$ & CHD & $\begin{array}{l}\text { Whites: } 1.07(0.94-1.21) \\
\text { Blacks: } 1.13(0.91-1.40)\end{array}$ \\
\hline $\begin{array}{l}\text { Lahoz } \\
\text { et al. [42] }\end{array}$ & 2001 & $242 / 1668$ & $11-65$ & US white men & Cohort & Any $\mathrm{e}^{\mathrm{a}}$ & CVD & $1.46(0.99-2.15)$ \\
\hline $\begin{array}{l}\text { Lahoz } \\
\text { et al. [42] }\end{array}$ & 2001 & $121 / 1739$ & $9-62$ & US white women & Cohort & Any e $4^{\mathrm{a}}$ & CHD & $1.36(0.78-2.38)$ \\
\hline $\begin{array}{l}\text { Bennett } \\
\text { et al. [16] }\end{array}$ & 2007 & $37,850 / 82,727^{\mathrm{c}}$ & NA & Mixed studies & $\begin{array}{l}\text { Meta-analysis of } 121 \\
\text { case-control studies } \\
\text { with } 500+\end{array}$ & Any $\mathrm{e}^{\mathrm{a}}$ & CHD & $1.06(0.99-1.13)$ \\
\hline $\begin{array}{l}\text { Song } \\
\text { et al. [13] }\end{array}$ & 2004 & $15,492 / 32,965$ & NA & Mixed studies & $\begin{array}{l}\text { Meta-analysis of } 48 \\
\text { case-control studies }\end{array}$ & Any $\mathrm{e}^{\mathrm{a}}$ & CHD & $1.42(1.26-1.61)$ \\
\hline $\begin{array}{l}\text { Anand } \\
\text { et al. [14] }\end{array}$ & 2009 & $25,348 / 51,484$ & $30-64$ & $\begin{array}{l}\text { Asian, European, } \\
\text { Arab, Nepalese }\end{array}$ & Case control & $\mathrm{e} 4^{\mathrm{a}}$ & MI & $1.07(1.01-1.28)$ \\
\hline $\begin{array}{l}\text { Keavney } \\
\text { et al. [15] }\end{array}$ & 2004 & $4685 / 3420$ & $30-64$ & UK whites & Case control & $\begin{array}{l}\text { Per e4 allele } \\
\text { vs e } 2 / \mathrm{e} 3\end{array}$ & Nonfatal MI & $1.16(1.06-1.27)$ \\
\hline $\begin{array}{l}\text { Georgoulias } \\
\text { et al. [22] }\end{array}$ & 2009 & 410 & $40-87$ & Greek & Patient group & Any e $4^{\mathrm{a}}$ & $\begin{array}{l}\text { Myocardial } \\
\text { perfusion } \mathrm{SSS}>2^{\mathrm{b}}\end{array}$ & $35.8(13.1-98.1)$ \\
\hline $\begin{array}{l}\text { Frikke-Schmidt } \\
\text { et al. [43] }\end{array}$ & 2000 & $940 / 9241$ & $20-80$ & Danish men & Case-referent & $\mathrm{e} 4 / \mathrm{e}^{\mathrm{a}}$ & IHD & $1.16(0.96-1.41)$ \\
\hline $\begin{array}{l}\text { Liu } \\
\text { et al. [17] }\end{array}$ & 2003 & $385 / 373$ & $40-84$ & US men & Nested case control & Any e $4^{\mathrm{a}}$ & MI & $0.93(0.63-1.37)$ \\
\hline $\begin{array}{l}\text { Mooijaart } \\
\text { et al. [18] }\end{array}$ & 2006 & 546 & 85 & Dutch & Cohort & $\begin{array}{l}\text { e4/e3 } \\
\text { modified by } \\
\text { plasma APOE }\end{array}$ & $\begin{array}{l}\text { Cardiovascular } \\
\text { death }\end{array}$ & $\begin{array}{l}\text { Intermediate plasma } \\
\text { APOE: } 2.81^{\mathrm{c}}(1.02-7.74) \\
\text { High plasma } \\
\text { APOE: } 4.25^{\mathrm{c}}(1.38-13.0)\end{array}$ \\
\hline
\end{tabular}

APOE apolipoprotein E; CHD coronary heart disease; $C V D$ cardiovascular disease; IHD ischemic heart disease; MI myocardial infarction; SSS summed stress score; UK United Kingdom; US United States

${ }^{\text {a }}$ Versus e33

${ }^{\mathrm{b}}$ Severity of perfusion defect under stress

${ }^{\mathrm{c}}$ Intermediate and high plasma ApoE

Studies of stroke, hypertension, and carotid atherosclerosis from 2000 to 2010

\begin{tabular}{|c|c|c|c|c|c|c|c|c|}
\hline Study & Year & $\begin{array}{l}\text { Cases/sample } \\
\text { or controls }\end{array}$ & $\begin{array}{l}\text { Age } \\
\text { range, } y\end{array}$ & Ethnic group & Design & APOE & Outcome & $\begin{array}{l}\text { Risk estimate } \\
(95 \% \mathrm{CI})\end{array}$ \\
\hline $\begin{array}{l}\text { McCarron } \\
\text { et al. [44] }\end{array}$ & 1999 & 9 studies & NA & $\begin{array}{l}\text { Japanese, Canadian, } \\
\text { European }\end{array}$ & $\begin{array}{l}\text { Meta-analysis of } 9 \\
\text { case-control studies }\end{array}$ & Any $\mathrm{e} 4^{+}$ & Ischemic CVD & $1.68(1.36-2.09)$ \\
\hline $\begin{array}{l}\text { Slooter } \\
\text { et al. [20] }\end{array}$ & 2004 & $149 / 6852$ & $55+$ & Dutch & Cohort & $\mathrm{e} 3 / \mathrm{e} 4 \mathrm{e} 4 / \mathrm{e} 4$ & Ischemic stroke & $\begin{array}{l}0.9(0.6-1.3) \\
0.6(0.1-2.5)\end{array}$ \\
\hline $\begin{array}{l}\text { van Vliet } \\
\text { et al. [34] }\end{array}$ & 2007 & $99 / 561$ & $85+$ & Dutch & Cohort & $\mathrm{e} 3 / \mathrm{e}^{+}$ & Stroke & $3.01(1.34-6.74)$ \\
\hline $\begin{array}{l}\text { Wang } \\
\text { et al. [45•] }\end{array}$ & 2009 & $396 / 396$ & 57 (mean) & Han Chinese & Case control & Any e $4^{+}$ & Stroke & $1.50(1.13-1.91)$ \\
\hline $\begin{array}{l}\text { Sturgeon } \\
\text { et al. [46] }\end{array}$ & 2007 & $180 / 5054$ & $45-64$ & US white men & Cohort & Any e $4^{+}$ & Ischemic stroke & $0.98(0.70-1.38)$ \\
\hline $\begin{array}{l}\text { Sturgeon } \\
\text { et al. [46] }\end{array}$ & 2007 & $97 / 1499$ & $45-64$ & US black men & Cohort & Any e $4^{+}$ & Ischemic stroke & $0.77(0.49-1.24)$ \\
\hline $\begin{array}{l}\text { Banerjee } \\
\text { et al. [47] }\end{array}$ & 2007 & 6107 & $50-70$ & Asian & Meta-analysis & Any e $4^{+}$ & Stroke & $1.47(1.00,2.15)$ \\
\hline
\end{tabular}




\begin{tabular}{|c|c|c|c|c|c|c|c|c|}
\hline $\begin{array}{l}\text { Lahoz } \\
\text { et al. [42] }\end{array}$ & 2001 & $242 / 1668$ & $11-65$ & US white men & Cohort & Any e $4^{+}$ & CVD & $1.46(0.99-2.15)$ \\
\hline $\begin{array}{l}\text { Niu } \\
\text { et al. [10] }\end{array}$ & 2009 & $1812 / 1762$ & $40+$ & Asian & $\begin{array}{l}\text { Meta-analysis of } 6 \\
\text { case-control studies }\end{array}$ & Any e $4^{+}$ & Hypertension & $1.97(1.11-3.52)$ \\
\hline $\begin{array}{l}\text { Volcik } \\
\text { et al. [19] }\end{array}$ & 2006 & 15,792 & $45-64$ & US white and black & Cohort & Any e $4^{+}$ & Carotid IMT (mean [SE]) ${ }^{\mathrm{a}}$ & e4: $0.74(0.003)$ \\
\hline $\begin{array}{l}\text { Debette } \\
\text { et al. [48] }\end{array}$ & 2006 & 5856 & $65+$ & European & Cohort & e4/e4 vs. e33 & Carotid plaque & $2.12(1.27-3.53)$ \\
\hline $\begin{array}{l}\text { Beilby } \\
\text { et al. [49] }\end{array}$ & 2003 & 1109 & $27-77$ & Australian white men & Cross-sectional & $\mathrm{e} 4 / \mathrm{e} 4 \mathrm{e} 3 / \mathrm{e} 4$ & Carotid plaque & $\begin{array}{l}2.85(0.49-16.6) \\
1.79(1.01-3.17)\end{array}$ \\
\hline
\end{tabular}

$A P O E$ apolipoprotein E; $C V D$ cardiovascular disease; IMT intimal media thickness

${ }^{\text {a }} P<0.05$ versus e 33

The apolipoprotein E (APOE) genotype is a genetic risk factor for dementia, Alzheimer's disease, and CVD. It is among the more common genotypes. It includes 3 alleles (e2, e3, e4) and 6 genotypes (e22, e23, e24, e33, e34, e44) that occur on chromosome $19 \mathrm{q} 3.2$. The e3 allele is the most common of the three and may be considered an ancestral allele. The e4 allele is more common in people of Northern European ancestry and lower in those of Asian ancestry [5]. Those with at least one e4 allele are at increased risk for CVD outcomes, and homozygosity for e4 (ie, e4/e4) increases risk further. It is well established that the presence of an e4 allele is linked to higher LDL-C levels; this is found even at younger ages, and LDL-C increases more rapidly with age in those with the e4 allele [6].

Apolipoprotein $\mathrm{E}$ is often found to interact with environmental risk factors, such as smoking or diet, to increase risk. Compared with e2 or e3, the e4 allele may contribute to earlier and higher mortality, which in turn contributes to a lower occurrence of the e4 allele in older compared with younger people [7-9]. Apolipoprotein E is often reported to modify the effects of environmental risk factors such as diet, smoking, or physical activity on cardiovascular outcomes.

Multiple individual studies, reviews, and metaanalyses have previously examined and summarized the influence of the APOE genotype on the risk of CVD. Most studies have focused on CHD, atherosclerosis, hypertension, and ischemic stroke, and some mechanistic studies have evaluated the role of lipids and inflammation in the links between apolipoprotein e4 and vascular outcomes. This review includes only studies published after 1998 that were sufficiently large to have statistically significant effects. In addition, only studies for which the referent or target population was identifiable were selected. This review is divided into studies examining 1) cerebrovascular diseases, including ischemic stroke, hypertension, or carotid atherosclerosis; and 2) studies examining CHD, lipids, and coronary atherosclerosis. Only studies in which there were older adults were included, with the exception of a longitudinal study of young adults modeling change over time in LDL-C in relation to apolipoprotein E [6]. Only a few studies that are restricted to older populations (age $\geq 65$ years) have been done of the effects of apolipoprotein $\mathrm{E}$ on these outcomes. Most studies include middle-aged individuals with smaller numbers of older individuals, and they do not report apolipoprotein $\mathrm{E}$ effects by age strata or test interactions between apolipoprotein $\mathrm{E}$ and age. Therefore, information about the differences between younger and older people in the effects of apolipoprotein E on vascular outcomes is limited. The effects of population heterogeneity by nationality, race, or ethnicity on apolipoprotein $\mathrm{E}$ and vascular outcomes is addressed in a number of recent studies.

\section{Stroke}

Ischemic stroke is the most common form of stroke and the most frequent stroke outcome studied in relation to apolipoprotein e4. Three of the publications included here did not distinguish ischemic from hemorrhagic stroke. Overall, the risk of ischemic stroke in those with an e4 compared with an e3 allele ranges from a risk of 0.77 (95\% CI, 0.49-1.24) in US middle-aged black men [46] to 3.01 (95\% CI, 1.34-6.74) in Dutch people over the age of 85 years [34]. Among studies of people of Asian origin, the elevated risk of stroke associated with apolipoprotein e4 is more consistent (around 1.50 for e4 vs e3) than in people of European origin, in whom it ranges from 0.90 to 1.68 in samples of middle-aged individuals [20, 44].

Hypertension and carotid atherosclerosis are common mechanisms related to stroke risk. Only one recent study has examined the association between apolipoprotein e4 and hypertension [10], yielding a risk of 1.97 (95\% CI, 1.113.52) in a meta-analysis of six cohort studies of Asians [46]. In addition, four studies in various population groups have reported significant increases in carotid atherosclerosis or carotid plaques in those with an e4 compared with an e3 
allele $[19,48,49]$. Of all the studies of apolipoprotein $\mathrm{E}$ and cerebrovascular disease that we reviewed, only four were restricted to people over the age of 55 years and none examined age-specific effects or tested interactions between apolipoprotein E and age [20, 34, 47, 48].

Notable among these studies are the following. 1) The only study to focus on elderly people (age $\geq 85$ years) found that the effects of the e3/e 3 and e3/e4 genotypes on stroke were mediated by plasma apolipoprotein E levels [34]. In e3/e4 carriers, a 1-SD difference in plasma apolipoprotein $\mathrm{E}$ was associated with a threefold increase in stroke risk $(P=0.002)$. In the e3/e3 genotype, this risk was $1.95(P=0.002)$. Stroke risk in e2 carriers was not mediated by plasma apolipoprotein E. 2) A meta-analysis of six studies of hypertension risk including only Asian participants that compared the e 3 to the e 4 allele found that the odds of hypertension were elevated in e4 carriers [47]. The summary estimate was more consistent than studies of Europeans. It is possible that there is less subpopulation heterogeneity in this group of Asian studies than in European studies.

\section{Coronary Heart Disease}

In the current literature, several large cohort studies report that the apolipoprotein e4 allele is associated with an increased risk of CHD, with a risk ranging between 1.1 and 2.0 [11-16]. Six of the 13 found a significantly increased risk of CHD in e 4 carriers. Three of the 13 studies found no association between the e4 allele and CHD [17-19]. Mooijaart et al.'s study [18] was the only populationbased study we found that restricted enrollment to elderly participants who were Dutch and $\geq 85$ years of age. Some of these studies may have lacked power to detect differences in CHD risk due to small sample size.

In a Dutch cohort study of 6852 men and women 55 years of age were followed for up to 8 years, the authors reported that the e4 allele was weakly associated with myocardial infarction, with e3/e4 individuals experiencing no increased risk $(\mathrm{RR}=1.0 ; 95 \% \mathrm{CI}, 0.7-1.4)$ compared with e3/e3 individuals [20]. In the same study, e4/e4 individuals, who made up a small proportion of the sample $(n=162)$, experienced an increased risk that was not statistically significant (relative risk $=1.7 ; 95 \%$ CI, 0.8-3.6) [20].

In a cohort study of 25,630 English men and women aged 40 to 79 years who were followed for up to 11 years, individuals with the e4 allele experienced a slightly higher risk for CHD (hazard ratio $=1.09 ; 95 \%$ CI, 1.0-1.19) [21•]. This relation was mediated by the ratio of low-density lipoprotein (LDL) to high-density lipoprotein (HDL); adding this variable to the regression models changed the hazard ratio to $1.06(95 \% \mathrm{CI}, 0.95-1.18)$, but the association remained statistically significant.

A cohort study of 1094 Swedish men and women 75 years or older at baseline who were followed for up to 18 years found Individuals with the e4 allele were significantly more likely to die than individuals who were homozygous for the e 3 allele over the 18 years of follow-up $(\mathrm{RR}=1.22 ; 95 \% \mathrm{CI}, 1.07-1.41)$ [9]. The authors investigated whether this relation was modified by ischemic heart disease or dementia. They found that increased risk of mortality was mediated by dementia but not by ischemic heart disease, but gender was an effect modifier.

A 2007 meta-analysis of 121 large studies found that individuals with the e4 allele had a slightly higher risk of CHD (odds ratio $=1.06 ; 95 \%$ CI, 0.99-1.13) [16]. There are very few large studies examining the role of apoe4 in relation to coronary atherosclerosis. One study of patients aged 61 years (mean) who underwent exercise-rest myocardial perfusion single positron emission computed tomography (SPECT) reported that individuals who were homozygous for e3 and e4 and individuals who were heterozygous for e4 had significantly higher values of a summed stress score (SSS) compared with those who were heterozygous for the e3 allele $(P<0.001)$ [22]. After adjustment for demographic and clinical risk factors, both APOE genotypes were independent predictors, with a cumulative contribution for the prediction of SSS and summed difference score. All APOE4 genotypes had higher levels of abnormal SSS, indicating they are linked to coronary atherosclerosis.

\section{Cardiovascular Mechanisms}

Lipids

Many studies have found that individuals with the apolipoprotein e4 allele have higher plasma LDL levels than individuals without the apolipoprotein e4 allele [16, $18,19,21 \cdot, 23]$. For example, work by Giltay et al. [23] reported that LDL-C was significantly $(P<0.001)$ lower in those with the e2/e2 or the e3/e2 genotype (mean of $3.2 \mathrm{mmol} / \mathrm{L}$ [ $95 \% \mathrm{CI}, 3.0-3.5]$ ) than in those with the e $3 / 4$ (mean of $4.1 \mathrm{mmol} / \mathrm{L}$ [95\% CI, 3.9-4.2]) or e4/e4 genotype (mean of $4.5 \mathrm{mmol} / \mathrm{L}$ [95\% CI, 3.9-5.2]). Similarly, highdensity lipoprotein cholesterol (HDL-C) was significantly $(P<0.001)$ higher in those with the e2/e2 (mean of $1.31 \mathrm{mmol} / \mathrm{L}$ [95\% CI, $1.25-1.37 \mathrm{mmol} / \mathrm{L}]$ ) and e3/e2 genotypes (mean of $1.24 \mathrm{mmol} / \mathrm{L}$ [95\% CI, 1.14-1.34]) than in those with the e4/e3 (mean of 1.20 [95\% CI, 1.16-1.23]) or the e4/e4 (mean of 1.17 [95\% CI, 1.01-1.34]) genotypes.

It is less clear whether this apolipoprotein-related increase in LDL leads to an increased risk of CVD. Two recent cohort 
studies suggest that plasma lipid levels mediate the relationship between apolipoprotein e4 genotypes and CHD [15, 21 •]. However, three of these studies reported that the apolipoprotein e4 allele is associated with significantly higher plasma LDL levels but not associated with CHD. In a 2007 meta-analysis of 82 large case-control studies, e4/e3 individuals had $0.13 \mathrm{mmol} / \mathrm{L}$ (95\% CI, 0.09-0.16) higher mean plasma LDL levels than e3/e3 individuals [16], and in a cohort of 22,279 European men aged 70 to 89 years at baseline, e4 carriers had significantly higher plasma LDL levels than non-e 4 carriers (mean difference of $0.23 \mathrm{mmol} / \mathrm{L}$ [95\% CI, 0.09-0.37]) over 15 years of follow-up [24].

A Dutch cohort study enrolled 561 individuals aged 85 years and followed them for an average of 4.2 years [18]. On average, plasma LDL-C levels were significantly higher in e4/e3 individuals than in e3/e3 individuals $(4.14 \mathrm{mmol} / \mathrm{L}$ [95\% CI, 3.96-4.32] vs $3.70 \mathrm{mmol} / \mathrm{L}$ [95\% CI, 3.60-3.80]; $P<0.001)$. Over the course of the study, 68 participants died of CVD. The authors reported that e4/e 3 and e $4 / 4$ carriers experienced a nonsignificant increased risk for cardiovascular mortality compared with e3/e3 individuals. The results of this study suggest that in the elderly, higher plasma LDL levels may not be associated with CVD. However, this study may have lacked power to detect differences in cardiovascular mortality due to smaller sample size.

A nested case-control study found significantly higher mean plasma LDL levels in individuals with the e3 allele compared with e3/e3 individuals (mean of $3.51 \mathrm{mmol} / \mathrm{L}[95 \%$ CI, 3.37-3.65] and $3.64 \mathrm{mmol} / \mathrm{L}$ [95\% CI, 3.56-3.72], respectively), but the authors did not find an increased risk of first myocardial infarction in e4 carriers compared with e3/e3 individuals (odds ratio $=0.87$; 95\% CI, 0.62-1.23) [17].

\section{Change in Exposure to Lipids and Other CVD Risk Factors} with Age

Risk factors for CVD tend to change with aging due to changes in lifestyle, selective survival, or age-dependent physiologic changes. There are also cohort effects representing time-dependent changes in exposure to risk factors. As an example, higher serum total cholesterol and LDL-C are wellaccepted as risk factors for CHD in middle age and early old age, but this association may disappear or reverse at older ages [25]. Raiha et al. [25] reported in a cohort of 347 people aged $\geq 65$ years that elevated total serum cholesterol did not predict vascular mortality but was a predictor of survival from death due to nonvascular causes. In fact, lower lipid levels were associated with poorer survival and higher with better survival from vascular mortality, and the effects of apolipoprotein e4 on death were unrelated to lipid levels. Current lipid levels in the elderly do not accurately represent lifetime exposure because many lifestyle factors (smoking, heavy alcohol use) that influence lipids change with age and these changes may modify lipid levels with advancing age [26]. To the extent that APOE genotypes tend to interact with vascular risk factors, changes in these risk factors can modify risk. Smoking is lower in elderly populations compared with younger groups ( $21 \%$ vs $9.3 \%$ in 2008). Some of this may be a cohort effect, due to selective survival of nonsmokers or due to smoking cessation. For these reasons, the impact of apolipoprotein e4 on vascular outcomes may be attenuated in elderly individuals if exposures vary by age and over time. Thus, at older ages, the deleterious effects of apolipoprotein e4 may not be exclusively mediated by dyslipidemia but also by other mechanisms.

\section{Inflammation}

Considerable evidence now exists linking inflammatory responses to an increased risk of CHD and stroke [27-30]. Inflammatory responses also increase in individuals with chronic conditions, so inflammation is as likely to be a marker of disease as a cause.

Inflammatory responses may be affected by the APOE genotypes. C-reactive protein, which is variously linked to CHD, varies by APOE genotype such that carriers of e2 and those with the e3/e3 genotype have higher levels of Creactive protein than those with e3/4 or e4/e4 [31, 32, 41]. In the very elderly ( $\geq 90$ years of age), the e 4 allele is linked to a decreased C-reactive protein response compared with younger people [33].

Fibrinogen, sometimes shown to be a CHD risk factor, is higher in elderly people with e3/e4 versus e3/e3 or e4/e4. Apolipoprotein e4 carriers have higher levels of the inflammatory cytokine interleukin (IL)- $1 \beta$ and lower levels of its receptor antagonist. Tumor necrosis factor- $\alpha$, and IL-6 are downregulated by the e4 allele. Plasma apolipoprotein E in very old people provokes an inflammatory response that may be independent of the genotypes e4/e4 or e3/e4 [34].

Homocysteine is a sulfur amino acid that is variably linked to stroke and to ischemic heart disease and sometimes to dementia [35]. A recent meta-analysis suggested that homocysteine is only a modest predictor of stroke and ischemic heart disease. Although the presence of apolipoprotein e4 may be associated with higher risk of stroke and ischemic heart disease, no studies have evaluated whether the apolipoprotein e4 allele modifies the effects of homocysteine on risk of stroke or of ischemic heart disease. Work by Ravaglia et al. [36] in an elderly Italian cohort study found that 4 carriers were less likely than noncarriers to have high homocysteine and were also less likely to have high Creactive protein. The implications of these results for stroke or ischemic heart disease risk are not clear; it may be that neither homocysteine nor C-reactive protein are biochemical pathways by which APOE genotype influences the risk of stroke or ischemic heart disease. It is also possible that selective 
survival mechanisms result in impaired immune response in carriers of apolipoprotein e4 alleles in old age [32, 37].

\section{Statins Use and APOE Genotype}

Statin use has increased rapidly over the past 10 to 15 years for the purpose of lowering LDL-C levels and preventing CHD and possibly stroke. Statins are highly effective in lowering LDL-C and may also affect inflammation [38]. Although apolipoprotein $\mathrm{E}$ is linked to LDL-C, relatively few studies have been able to evaluate the effectiveness of statin therapy in those with the e4 allele compared with the e 3 or e 2 allele. A genome-wide association study was conducted on a sample of 1984 men with a mean age of 62 years [39]. They were enrolled in a randomized trial to test the effects of low-dose versus high-dose statins on cardiovascular outcomes. This trial evaluated 17 single nucleotide polymorphisms in relation to LDL-C response to treatment over an 8-week period. Of these, only APOE genotypes met study criteria; the least LDL-C change occurred in those with an e4/4 genotype and the largest change occurred in those with an e $2 / 2$ genotype. In a series of patients with and without familial hypercholesterolemia, the effects were tested of apolipoprotein E on lipid response to either atorvastatin for those with familial hypercholesteremia or to fenofibrate in those without familial hypercholesteremia [40]. Among those with familial hypercholesteremia, the largest change occurred in those with the e2 allele (46-mg/dL decline) and the smallest change occurred in carriers of the e4 allele $(34.5-\mathrm{mg} / \mathrm{dL}$ decline; comparison of baseline to post-treatment in both alleles was $P<0.0001)$. Among those without familial hypercholesteremia, a similar pattern of change in LDL-C did not occur and the results were similar for carriers of e2,e3 and e4 alleles.

\section{Conclusions}

Our summary of recent research on the effects of the APOE genotypes on CVD in the elderly reveals a complex system of relationships. APOE genotypes clearly influence lipids and potentially inflammation, and may be linked to atherosclerosis and hypertension. However, the association of these biomarkers with CVD outcomes is altered in the elderly, in part by age- and time-dependent changes in exposure. The occurrence of APOE4 genotypes in older populations has been seen to decline as well. From a population perspective, this may mean that the fraction of CVD cases attributable to apolipoprotein e4 may be smaller and that the ability of e4 to influence CVD risk by increasing LDL-C is more limited. There are few studies of these issues in elderly people, and most of the research includes middle-aged individuals. This age inclusion would tend to attenuate the ability to observe age-specific effects. The more recent research has provided some information about subpopulation heterogeneity in the occurrence of e4 alleles and about related differences in effects on CVD. The work by Niu et al. [10] is of particular value as it is one of the only studies on $\mathrm{e} 4$ and hypertension in Asians.

The efficacy of active lipid-lowering interventions such as statin use or diet on CVD may or may not be affected by genetic risk factors such as apolipoprotein E. Most trials are not designed to test whether the apolipoprotein genotypes affect treatment efficacy. Given that in some populations e4 carriers comprise as much as $25 \%$ of the population, this is an important omission. Clearly, more research is needed that can help to elucidate the mechanisms by which apolipoprotein $\mathrm{E}$ affects CVD in older populations.

Disclosure No potential conflicts of interest relevant to this article were reported.

Open Access This article is distributed under the terms of the Creative Commons Attribution Noncommercial License which permits any noncommercial use, distribution, and reproduction in any medium, provided the original author(s) and source are credited.

\section{References}

Papers of particular interest, published recently, have been highlighted as:

- Of importance

1. American Heart Association: Cardiovascular disease statistics; 2006. Available at http://www.americanheart.org/presenter.jhtml? identifier $=4478$. Accessed May 2, 2010.

2. Centers for Disease Control: Health data statistics; 2005. Available at http://www.cdc.gov/nchs/hdi.htm. Accessed May 2, 2010.

3. Centers for Disease Control: Medicare expenditures for chronic conditions; 2005. Available at http://205.207.175.93/HDI/Table Viewer/tableView.aspx?ReportId=102. Accessed May 2, 2010.

4. Mann D, Reynolds K, Smith D, et al.: Trends in statin use and low-density lipoprotein cholesterol levels among US adults: impact of the 2001 National Cholesterol Education Program guidelines. Ann Pharmacother 2008, 42:1208-1215.

5. Hu P, Qin YH, Jing CX, et al.: Does the geographical gradient of ApoE4 allele exist in China? A systemic comparison among multiple Chinese populations. Mol Biol Rep 2010 (in press).

6. Gronroos P, Raitakari OT, Kahonen M, et al.: Influence of apolipoprotein E polymorphism on serum lipid and lipoprotein changes: a 21-year follow-up study from childhood to adulthood. The Cardiovascular Risk in Young Finns Study. Clin Chem Lab Med 2007, 45:592-598.

7. Gerdes LU, Jeune B, Ranberg KA, et al. : Estimation of apolipoprotein $E$ genotype-specific relative mortality risks from the distribution of genotypes in centenarians and middle-aged men: apolipoprotein E gene is a "frailty gene," not a "longevity gene". Genet Epidemiol 2000, 19:202-210.

8. Lewis SJ, Brunner EJ: Methodological problems in genetic association studies of longevity-the apolipoprotein E gene as an example. Int J Epidemiol 2004, 33:962-970. 
9. Rosvall L, Rizzuto D, Wang HX, et al.: APOE-related mortality: effect of dementia, cardiovascular disease and gender. Neurobiol Aging 2009, 30:1545-1551.

10. Niu W, Qiu Y, Qian Y, et al.: The relationship between apolipoprotein E epsilon2/epsilon3/epsilon4 polymorphisms and hypertension: a meta-analysis of six studies comprising 1812 cases and 1762 controls. Hypertens Res 2009, 32:1060-1066.

11. Scuteri A, Bos $\mathrm{AJ}$, Zonderman $\mathrm{AB}$, et al.: Is the apoE4 allele an independent predictor of coronary events? Am J Med 2001, 110:28-32.

12. Scuteri A,Najjar SS, Muller D, et al.: apoE4 allele and the natural history of cardiovascular risk factors. Am J Physiol Endocrinol Metab 2005, 289:E322-E327.

13. Song Y, Stampfer MJ, Liu S: Meta-analysis: apolipoprotein E genotypes and risk for coronary heart disease. Ann Intern Med 2004, 141:137-147.

14. Anand SS, Zie C, Pare G, et al.: Genetic variants associated with myocardial infarction risk factors in over 8000 individuals from five ethnic groups: The INTERHEART Genetics Study. Circ Cardiovasc Genet 2009, 2:16-25.

15. Keavney B, Palmer A, Parish S, et al.: Lipid-related genes and myocardial infarction in 4685 cases and 3460 controls: discrepancies between genotype, blood lipid concentrations, and coronary disease risk. Int J Epidemiol 2004, 33:1002-1013.

16. Bennet AM, Di Angelantonio E, Ye Z, et al.: Association of apolipoprotein E genotypes with lipid levels and coronary risk. JAMA 2007, 298:1300-1311.

17. Liu S, Ma J, Ridker PM, et al.: A prospective study of the association between APOE genotype and the risk of myocardial infarction among apparently healthy men. Atherosclerosis 2003, 166:323-329.

18. Mooijaart SP, Berbee JF, van Heemst D, et al.: ApoE plasma levels and risk of cardiovascular mortality in old age. PLoS Med 2006, 3:e176.

19. Volcik KA, Barkely RA, Hutchinson RG, et al.: Apolipoprotein E polymorphisms predict low density lipoprotein cholesterol levels and carotid artery wall thickness but not incident coronary heart disease in 12,491 ARIC study participants. Am J Epidemiol 2006, 164:342-348.

20. Slooter AJ, Cruts M, Hofman A, et al.: The impact of APOE on myocardial infarction, stroke, and dementia: the Rotterdam Study. Neurology 2004, 62:1196-1198.

21. - Ward H, Mitrou PN, Bowman R, et al.: APOE genotype, lipids, and coronary heart disease risk: a prospective population study. Arch Intern Med 2009, 169:1424-1429. This is a large prospective cohort study $(n=22,169)$ of CHD incidence in middle-aged people in the United Kingdom. Although the e4 allele was associated with higher $L D L-C$ and initially increased the risk of CHD, this was accounted for by covariate adjustments.

22. Georgoulias P, Wozniak G, Samara M, et al.: Impact of $A C E$ and ApoE polymorphisms on myocardial perfusion: correlation with myocardial single photon emission computed tomographic imaging. J Hum Genet 2009, 54:595-602.

23. Giltay EJ, van Reedt Dortland AK, Nissinen A, et al.: Serum cholesterol, apolipoprotein E genotype and depressive symptoms in elderly European men: the FINE study. J Affect Disord 2009, 115:471-477.

24. Giltay EJ, Nissinen A, Giampaoli S, et al.: Apolipoprotein E genotype modifies the association between midlife lung function and cognitive function in old age. Dement Geriatr Cogn Disord 2009, 28:433-441.

25. Raiha I, Marniemi J, Puukka P, et al.: Effect of serum lipids, lipoproteins, and apolipoproteins on vascular and nonvascular mortality in the elderly. Arterioscler Thromb Vasc Biol 1997, 17:1224-1232.
26. Kaplan GA, Haan MN, Wallace RB: Understanding changing risk factor associations with increasing age in adults. Annu Rev Public Health 1999, 20:89-108.

27. Napoli M, Schwaninger M, Cappelli R, et al.: Evaluation of $C$ reactive protein measurement for assessing the risk and prognosis in ischemic stroke: a statement for health care professionals from the CRP Pooling Project members. Stroke 2005, 36:1316-1329.

28. Kornman KS: Interleukin 1 genetics, inflammatory mechanisms, and nutrigenetic opportunities to modulate diseases of aging. Am J Clin Nutr 2006, 83:475S-483S.

29. Phan HM, Alpert JS, Fain M: Frailty, inflammation, and cardiovascular disease: evidence of a connection. Am J Geriatr Cardiol 2008, 17:101-107.

30. Sie MP, Sayed-Tabatabaei FA, Oei HH, et al.: Interleukin 6 $174 \mathrm{~g} / \mathrm{c}$ promoter polymorphism and risk of coronary heart disease: results from the rotterdam study and a meta-analysis. Arterioscler Thromb Vasc Biol 2006, 26:212-217.

31. Marz W, Scharnagl H, Hoffman MM, et al.: The apolipoprotein $E$ polymorphism is associated with circulating $C$-reactive protein (the Ludwigshafen risk and cardiovascular health study). Eur Heart J 2004, 25:2109-2119.

32. Haan MN, Aiello AE, West NA, et al.: C-reactive protein and rate of dementia in carriers and non carriers of Apolipoprotein APOE4 genotype. Neurobiol Aging 2008, 29:1774-1782.

33. Rontu R, Ojala P, Hervonen A, et al.: Apolipoprotein E genotype is related to plasma levels of C-reactive protein and lipids and to longevity in nonagenarians. Clin Endocrinol (Oxf) 2006, 64:265270.

34. van Vliet P, Mooijaart SP, de Craen AJ,et al.: Plasma levels of apolipoprotein E and risk of stroke in old age. Ann N Y Acad Sci 2007, 1100:140-147.

35. Homocysteine Studies Collaboration: Homocysteine and risk of ischemic heart disease and stroke: a meta-analysis. JAMA 2002, 288:2015-2022.

36. Ravaglia G, Forti P, Maioli F, et al.: Apolipoprotein E e4 allele affects risk of hyperhomocysteinemia in the elderly. Am J Clin Nutr 2006, 84:1473-1480.

37. Aiello AE, Nguyen $\mathrm{HO}$, Haan $\mathrm{MN}$ : C-reactive protein mediates the effect of apolipoprotein $E$ on cytomegalovirus infection. $\mathrm{J}$ Infect Dis 2008, 197:34-41.

38. McMurray JJ, Kjekshus J, Gullestad L, et al.: Effects of statin therapy according to plasma high-sensitivity C-reactive protein concentration in the Controlled Rosuvastatin Multinational Trial in Heart Failure (CORONA): a retrospective analysis. Circulation 2009, 120:2188-2196.

39. Thompson JF, Hyde CL, Wood LS, et al.: Comprehensive wholegenome and candidate gene analysis for response to statin therapy in the Treating to New Targets (TNT) cohort. Circ Cardiovasc Genet 2009, 2:173-181.

40. Christidis DS, Liberopoulos EN, Kakafika AI, et al.: The effect of apolipoprotein E polymorphism on the response to lipid-lowering treatment with atorvastatin or fenofibrate. J Cardiovasc Pharmacol Ther 2006, 11:211-221.

41. Kravitz BA, Corrada MM, Kawas $\mathrm{CH}$ : High levels of serum $C$ reactive protein are associated with greater risk of all-cause mortality, but not dementia, in the oldest-old: results from The 90+ Study. J Am Geriatr Soc 2009, 57:641-646.

42. Lahoz C, Schaefer EJ, Cupples LA, et al.: Apolipoprotein E genotype and cardiovascular disease in the Framingham Heart Study. Atherosclerosis 2001, 154:529-537.

43. Frikke-Schmidt R, Tybjaerg-Hansen A, Steffensen R, et al:: Apolipoprotein E genotype: epsilon 32 women are protected while epsilon43 and epsilon44 men are susceptible to ischemic heart disease: the Copenhagen City Heart Study. J Am Coll Cardiol 2000, 35:1192-1199. 
44. McCarron MO, Delong D, Alberts MJ: APOE genotype as a risk factor for ischemic cerebrovascular disease: a meta-analysis. Neurology 1999, 53:1308-1311.

45. - Wang B, et al.: Association of genetic variation in apolipoprotein $E$ and low density lipoprotein receptor with ischemic stroke in Northern Han Chinese. J Neurol Sci 2009, 276:118-122. This study reported a twofold increased risk of ischemic stroke in Han Chinese carriers of the e4 allele that was independent of hypertension.

46. Sturgeon JD, Folsom AR, Bray MS, et al.: Apolipoprotein E genotype and incident ischemic stroke: the Atherosclerosis Risk in Communities Study. Stroke 2005, 36:2484-2486.
47. Banerjee I, Gupta V, Ganesh S: Association of gene polymorphism with genetic susceptibility to stroke in Asian populations: a metaanalysis. J Hum Genet 2007, 52:205-219.

48. Debette S, Lambert JC, Gariepy J, et al.: New insight into the association of apolipoprotein E genetic variants with carotid plaques and intima-media thickness. Stroke 2006, 37:2917-2923.

49. Beilby JP, Hunt CC, Palmer LJ, et al.: Apolipoprotein E gene polymorphisms are associated with carotid plaque formation but not with intima-media wall thickening: results from the Perth Carotid Ultrasound Disease Assessment Study (CUDAS). Stroke 2003, 34:869-874. 